\title{
Pembangunan Jiwa Berasaskan Konsep al-Nafs Menurut Perspektif Ibn Bajjah
}

\author{
Muhammad Latiffi Mahadzir \\ Universiti Sains Malaysia, lattifi-pimlm@usm.my \\ Shaik Abdullah Hassan Mydin \\ Universiti Sains Malaysia, abdullah@usm.my \\ Mohd Afifuddin Mohamad \\ Universiti Sains Malaysia, afifuddin@usm.my \\ Rafidah Ramya @ Abd Rahim \\ Universiti Sains Malaysia, fida@usm.my
}

DOI: https://doi.org/10.22452/usuluddin.sp2019no1.1

\begin{abstract}
Abstrak
Artikel ini memperkenalkan Ibn Bajjah sebagai salah seorang tokoh ilmuwan Islam Andalusia yang berpengaruh dalam pembangunan jiwa berasaskan konsep al-Nafs. Objektif pertama, meneliti latar belakang dan sejarah hidup Ibn Bajjah. Kedua, menjelaskan tentang konsep al-Nafs menurut perspektif Islam. Ketiga, menerangkan tentang proses pembangunan jiwa menurut pandangan Ibn Bajjah mengikut konsep alNafs. Rumusan awal artikel ini menjelaskan tentang Ibn Bajjah merupakan tokoh pemikir yang menghuraikan tentang konsep al-Nafs dari sudut ilmu, pemikiran dan tauhid. Kedua, Ibn Bajjah menekankan tentang kepentingan proses pembangunan jiwa berasaskan konsep alNafs bagi melahirkan hubungan antara hamba yang dicipta dengan Pencipta. Akhirnya penulisan berkaitan Ibn Bajjah ini diharapkan dapat memberi manfaat kepada para pendidik dan pemuda dalam meneladani tokoh pemikir Islam yang kreatif dalam kehidupan mereka demi menjaga hubungan dengan Allah SWT secara harmonis dalam usaha membangunkan modal insan yang holistik.
\end{abstract}

Kata kunci: pembangunan jiwa, Ibn Bajjah, konsep al-Nafs, tauhid dan tasawuf

\section{The Development of the Soul based on the Concept of al-Nafs According to the Ibn Bajjah Perspective}

\section{Abstract}

This article aims to introduce Ibn Bajjah as one of Andalusian Islamic scholars as an influential figures in soul development according to the al-Nafs context. The first objective is to examine the background and life history of Ibn Bajjah's. Secondly, to explain the concept of al-Nafs from an Islamic perspective. Thirdly, to explain the process of soul development, according to Ibn Bajjah's view of the concept of al-Nafs. 
The initial review explained Ibn Bajjah as a thinker who has described the concept of al-Nafs from the point of knowledge, thought and faith. Secondly, to describe how Ibn Bajjah emphasized the importance of the process of soul development based on the concept of al-Nafs by expressing the relation between the servant and the creator. As a conclusion, it is hoped that the insight of Ibn Bajjah concept will benefit the educators and youth by learning and following the way of life of Islamic creative thinker in maintaining a harmonious relationship with Allah in the effort of developing the holistic human capital.

Keywords: soul development, Ibn Bajjah, concept of al-Nafs, tawhid and tasawwuf

\section{Pendahuluan}

Zaman kegemilangan Empayar Islam di Eropah, Andalusia mencapai puncak keemasannya. Kehebatannya membawa Eropah kepada dunia kemajuan yang lebih kompleks. Andalusia juga dikatakan mampu menyaingi Baghdad yang terkenal dengan Baitul Hikmah suatu ketika dahulu. Ramai orang Eropah mendalami pengajian di universiti-universiti Islam di Andalusia. Pada ketika itu, kebanyakan orang Islam telah menjadi guru bagi orang-orang Eropah.

Gustane Len Bon dalam bukunya Islamic and Arab Civilization, sebagaimana yang dikutip pandangan beliau oleh Sulaiman Noordin menyatakan bahawa ${ }^{1}$ :

Umat Islam mengkaji sains dengan tujuan untuk menggunakannya. Oleh itu, adalah tepat untuk memberikan gelaran kepada tamadun umat Islam sebagai guru kepada Eropah (Europe's Professor) kerana melalui mereka, sains Romawi dan Yunani ditemui semula dan dikembalikan kepada Eropah semasa ia keluar dari Zaman Kegelapan.

Ketika Eropah mengalami zaman kegelapan ilmu, masyarakat Islam di Andalusia sebaliknya telah mencapai kejayaan dalam bidang tersebut. Proses pembangunan peradaban unik ini mencakupi pelbagai disiplin ilmu seperti sejarah, falsafah, perundangan, ilmu bahasa, kesusasteraan Arab, geografi, perubatan, matematik dan astronomi ${ }^{2}$.

1 Sulaiman Noordin, Sains: Falsafah dan Islam (Bangi: Universiti Kebangsaan Malaysia, 1993), 194.

2 Anwar G. Chejne, Muslim Spain: It's History and Culture (Minneapolis: The University of Minnesota Press, 1974), 162 
Rasid Muhammad di dalam bukunya "Merintis Kecemerlangan Islam, Sumbangan, Cabaran dan Masa Hadapan Umat Muhammad" memetik kata-kata Robert Briffault dalam bukunya "Making of Humanity":

Ia adalah pengaruh Arab dan kebangkitan semula kebudayaan Moor (muslim), bukannya pada abad ke-15 bila mana renaissance mula berlaku. Sepanyol telah menjadi pusat kepada kelahiran semula Eropah, bukannya Itali. Eropah semakin terjerumus dalam kancah barbarism dan mencapai tahap kedunguan dan kejatuhan yang paling dalam ketika kota-kota puak Saracen (muslim) seperti Baghdad, Kaherah, Cordova dan Toledo berkembang menjadi pusat ketamadunan dan aktiviti intelektual. Di sanalah hidup baru bermula yang akhirnya membentuk fasa baru evolusi manusia. Ketika pengaruh kebudayaan mereka dirasai, maka bermulalah kehidupan baru.

Sejarah peradaban dunia menyaksikan Andalusia pernah melahirkan ramai intelektual Islam yang menguasai kepelbagaian bidang keilmuan. Kegiatan keilmuan ini disemarakkan lagi oleh tokoh-tokoh yang terkenal di zaman itu seperti Ibn Bajjah, Ibnu Rusyd, Ibnu Tuffail, dan ramai lagi. Nama-nama tersebut merupakan nama-nama besar dalam pelbagai cabang ilmu ${ }^{4}$. Malah ada juga di kalangan mereka yang menjadi pelopor bagi bidangbidang keilmuan tertentu. Hasil penemuan dan penulisan para intelektual Islam ini turut menjadi rujukan dalam pembelajaran di universiti Barat hingga ke masa kini.

Selama lapan abad, Islam pernah berjaya di bumi Eropah (Andalusia) dan membina tamadaun serta peradaban yang cemerlang. Namun, peradaban yang dibangunkan dengan susah payah dan kerja keras kaum muslimin itu, harus ditinggalkan dan dilepas begitu sahaja disebabkan kelemahan-kelemahan yang berlaku dikalangan kaum muslimin sendiri di samping kejayaan bangsa Eropah bangkit dari kemunduran dan kegelapan.

3 Rasid Muhamad, Merintis Kecemerlangan Islam: Sumbangan, Cabaran dan Masa Hadapan Umat Muhammad (Kuala Lumpur: Karya Bestari, 2010), 145.

4 Che Zaharah Abdullah, "Sumbangan dan Pengaruh Intelek Muslim Kepada Masyarakat: Kajian di Bandar Baru Bangi" (Disertasi, Universiti Kebangsaan Malaysia, 2001), 27. 
Kebangkitan yang meliputi semua elemen peradaban terutamanya dalam bidang politik, sains dan teknologi.

Kehadiran Islam dalam sejarah dan ketamadunan dunia, khususnya di Barat merupakan sesuatu yang tidak dapat disangkal lagi. Sejarah telah membuktikan hal ini. Tamadun Islam telah memberi Barat nilai dan semangat baru yang akhirnya membolehkan ia mampu muncul sebagai tamadun yang penting dan berpengaruh di dunia ${ }^{5}$.

Salah Seorang tokoh dalam Andalusia yang berpengaruh dalam pembinaan jiwa manusia adalah Ibn Bajjah

\section{Latar Belakang Ibn Bajjah}

Beliau bernama Abū Bakr Muhamad Ibn Yahyā bin al-Ṣā'̄̄gh atTujibi al-Andalusiā al-Saraqasți $\dot{1}^{6}$ atau dikenali dengan gelaran "Ibn Bajjah"7. Beliau berasal daripada keluarga at-Tujibi ${ }^{8}$ dan dilahirkan di Saragosa yang pada hari ini dikenali sebagai Aragon, Sepanyol pada tahun $457 \mathrm{H}(1065 \mathrm{M})^{9}$ pada zaman pemerintahan Raja Ahmad $\mathrm{II}^{10}$ (478-502H / 1085-1108M) ${ }^{11}$. Gelaran Ibn Bajjah

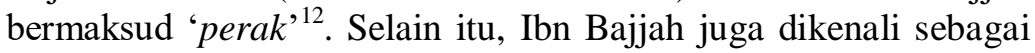

5 Che Zaharah, "Sumbangan dan Pengaruh Intelek Muslim Kepada Masyarakat: Kajian di Bandar Baru Bangi," 142.

6 Al-Saraqasti diambil daripada perkataan Saraqosta yang merupakan nama kepada sebuah bandar di Sepanyol iaitu Saragosa. Lihat Ibn Khallikans, terj. Mac Guckin De Slane, Biographical Dictionary, translated from the Arabic (Paris: Paris Printed , t.t.), vol. III: 134.

7 Kāmil Muḥammad Muhammad U’waiḍah, Ibn Bajjah al-Andālūsī al-Faylāsuf al-Khallaq (Beirut, Lubnan: Dār al-Kutub al-'Ilmiyyah, 1993), 99. Lihat juga Ibn Khallikans, Biographical Dictionary, 133.

8 Tujibi berasal daripada perkataan Tajibi yang diambil daripada asal perkataan Tujib. Lihat juga, Ibn Khallikans, Biographical Dictionary, 134.

9 Hafizah Dasuki, Ensiklopedia Islam, jld. II (Kuala Lumpur: Dewan Pustaka dan Bahasa, 2004), 151.

10 Raja Ahmad II ialah raja keempat dari kerajaan dinasti Bani Hud dan meninggal dunia pada tahun 532H / 1138M.

11 Takiruddin Hassan, Pemerintahan Kerajaan Dinasti Bani Umayyah Andalus (Sepanyol) (Johor Bahru: Perniagaan Jahabersa, 2013), 190.

12 Gazi Saloon, Jiwa dalam Pandangan Para Filosof Muslim (Bandung: Pustaka Hidayah, 2002), 257. Lihat juga Ibn Khallikans, Biographical Dictionary, 134. 
Avempace, Avenpace atau Aben Pace di Eropah ${ }^{13}$. Bapa beliau bernama Yahyā al-Sā'̄̄oh bekerja sebagai tukang emas ${ }^{14}$.

Ibn Bajjah hidup pada zaman pemerintahan kerajaan alMurabbitun yang diasaskan oleh Yahya Ibn Ibrahim al-Jaddail yang merupakan pemimpin Islam di Barbar dan dibantu oleh seorang ahli fiqh dan sufi iaitu Abdullah Ibn Yassin al-Jazuli kirakira pada abad pertengahan ke-11 Masihi. Beliau hidup dalam tiga era pemerintahan iaitu Yusof Ibn Tasyfin $(483 \mathrm{H} / 1090 \mathrm{M})$, Ali Ibn Yusof $(499 \mathrm{H} / 1106 \mathrm{M})$ dan Tasyfin Ibn Ali (573-539H/1143$1145 \mathrm{M})^{15}$.

Ibn Bajjah merupakan tokoh utama dalam sejarah falsafah Arab. Para ilmuwan sezaman dengannya telah menganggap beliau sebagai wakil ketua falsafah Arab dan sebagai ilmuwan ulung yang menjadi perintis memperkenalkan idea dan teori falsafah Aristotle selepas Ibn Sina al-Syaikh al-Ra' is ${ }^{16}$. Uni Iskandar Halib turut berpendapat bahawa Ibn Bajjah merupakan tokoh falsafah Andalusia yang terlibat di dalam usaha membuat komentar dan ulasan ke atas karya-karya Aristotle ${ }^{17}$.

Di samping itu, Ibn Bajjah juga seorang sasterawan dan juga ahli bahasa Sepanyol yang unggul $^{18}$. Para sejarawan memandangnya sebagai orang yang berpengetahuan luas dan menguasai tidak kurang daripada dua belas bidang ilmu. Oleh kerana beliau dapat menguasai ilmu sastera, tatabahasa dan

${ }^{13}$ Ma'an Ziyādah, Al-Harakah min al-Ṭabī'ah ilā ma Ba'da al-Ṭabī'ah Dirāsah fì Falsafah Ibn Bajjah al-Andalus (Beirut, Lubnan: Dār Iqra', 1985), 19.

14 Ibn Khallikans, Biographical Dictionary, 133.

${ }^{15}$ Hafizah Dasuki, Ensiklopedia Islam, 151.

16 M.S. Hassan Ma'sumi, Ibn Bajjah's 'Ilm Al-Nafs (New Delhi: Kitab Bhavan, 1992), 1.

17 Uni Iskandar Halib, "Pemikiran Ibn Rushd: Suatu Analisis Berhubung Masalah Falsafah dan Agama dalam Kitab Fașl Al-Maqal” (Tesis kedoktoran, Universiti Kebangsaan Malaysia, 2005), 22. Lihat juga, Thomas Glick, Stevan J. Livesey \& Faith Wallis, Medival Science, Technology and Medicene an Encyclopedia (New York: Routledge Taylor \& Francis Group, 2005), 244. Lihat Juga, F. Jamil Ragep, Sally P. Ragep \& Steven Livesey, "Tradition, Transmission Transformation", Proceedings of Two Conferences on PreModern Science Held at the University of Oklahoma (New York: E.J. Brill, 1996), 66. Lihat juga, Gerhard Bowering, The Princeton Encyclopedia of Islamic Political Thought (New Jersey: Princeton University Press, 2013), 233.

18 Thomas Glick, Stevan J. Livesey \& Faith Wallis, Medival Science, Technology and Medicene an Encyclopedia, 243. 
falsafah kuno ${ }^{19}$, tokoh-tokoh sezamannya memberi gelaran kepada beliau dengan gelaran "al-Syaikh al-Ra'is" yang membawa maksud "Guru Para Raja" selepas Ibn Sina ${ }^{20}$. Ibn Bajjah menjadi terkenal sebagai salah seorang ahli falsafah Muslim Arab terbesar dari Sepanyol. Bahkan, Ibnu Khaldun mengatakan bahawa ilmu Ibn Bajjah setanding dengan Ibnu Rusyd di Barat serta al-Farabi dan Ibnu Sina di Timur. Ibn Bajjah tercatat juga sebagai salah seorang penyair dan beliau juga adalah orang yang bersama-sama dengan Ibnu Tufail ${ }^{21}$ yang melontarkan kritikan serta memberi penjelasan Islam yang bersifat sistematik tentang ajaran Aristotelian $^{22}$.

Selain itu, Ibn Bajjah juga merupakan seorang ahli falsafah yang mengulas atau menerangkan falsafah Aristotle selepas Ibn Sina. Dengan kemasyhuran Ibn Bajjah, Abu Bakar Ibrahim alSharawi, gabenor Saragosa pada ketika itu telah melantik beliau menjadi pegawai tertinggi semasa pemerintahannnya. Beliau juga pernah menjadi seorang penyair dalam golongan al-Murabbitin yang dipimpin oleh Abu Bakar Ibrahim Ibn Tafalwit di samping mahir dalam bidang muzik ${ }^{23}$. Menurut Mohd Zamrus Mohd Ali, Ibn Bajjah sangat mahir bermain alat muzik Gambus ${ }^{24}$. M.S Hassan Ma'sumi juga turut berpandangan yang sama mengatakan bahawa Ibn Bajjah merupakan seorang penyair yang fasih dan

19 Thomas Glick, Stevan J. Livesey \& Faith Wallis, Medival Science, Technology and Medicene an Encyclopedia, 243.

${ }^{20}$ Mohammad Shaif Khan, Muslim Philosophy and Philosophers (New Delhi: Computer Codes, 1994), 80.

${ }^{21}$ Ibn Tufail juga seperti gurunya Ibn Bajjah. Beliau merupakan seorang yang pakar di dalam berbagai bidang ilmu pengetahuan seperti ilmu-ilmu agama, bahasa, matematik, fizik, logik, perubatan, geografi, sejarah, astronomi, sains, kesusateraan dan banyak lagi. Lihat Takiruddin Hassan, Pemerintahan Kerajaan Dinasti Bani Umayyah Andalus (Sepanyol) (Johor Bahru: Perniagaan Jahabersa, 2013), 193. Lihat juga, Thomas Glick, Stevan J. Livesey \& Faith Wallis, Medival Science, Technology and Medicene an Encyclopedia, 243.

22 Hafizah Dasuki, Ensiklopedia Islam, 152. Lihat juga, F. Jamil Ragep and Sally P. Ragep \& Steven Livesey, "Tradition, Transmission Transformation", Proceedings of Two Conferences on Pre-Modern Science Held at the University of Oklahoma, 65.

23 Hafizah Dasuki, Ensiklopedia Islam, 152

24 Mohd Zamrus Mohd Ali, "Disiplin al-Quran dan Hubungannya dengan Tradisi Intelektual Andalusia" (Disertasi, Universiti Sains Malaysia, 2010), 82. 
juga seorang pemuzik yang berbakat ${ }^{25}$. Sungguh pun begitu, menurut Zulkifli Hassan dan Hannani Harun, Ibn Bajjah juga merupakan seorang hafiz al-Quran ${ }^{26}$. Dalam masa yang sama beliau juga amat terkenal dalam bidang perubatan dan merupakan seorang doktor yang teragung yang pernah dilahirkan di Andalusia $^{27}$. Menurut Arief Abu Rabia, menyatakan bahawa Ibn Bajjah adalah seorang pakar dalam bidang perubatan di mana beliau telah menulis buku berkenaan ilmu perubatan dengan menggunakan tumbuhan untuk dijadikan ubat-ubatan ${ }^{28}$.

Ghazali Darusalam pula menyatakan bahawa Ibn Bajjah merupakan ekspertis dalam bidang perubatan, ilmu logik, ilmu falak (astronomi) dan ilmu muzik. Ghazali juga turut menyatakan kitab Ibn Bajjah yang berjudul Majmu' kini tersimpan di perpustakaan Berlin dan Oxford ${ }^{29}$. Menurut Azizan Baharudin, Ibn Bajjah juga merupakan seorang ahli zoologi ${ }^{30}$ yang membuat penyelidikan tentang pemburuan ${ }^{31}$. Menurut Uni Iskandar Halib, Ibn Bajjah merupakan guru tentang ilmu falsafah kepada Ibnu

25 M.S. Hassan Ma'sumi, Ibn Bajjah's 'Ilm Al-Nafs, 3. Lihat juga, Thomas Glick, Stevan J. Livesey \& Faith Wallis, Medival Science, Technology and Medicene an Encyclopedia, 243. Lihat juga, Gerhard, The Princeton Encyclopedia of Islamic Political Thought, 233.

${ }^{26}$ Zulkifli Hasan dan Hanani Harun, "Sumbangan Intelektual Islam dalam Seni," Jurnal Tamadun (2008), "Sihat http://zulkiflihasan.files.wordpress.com/2008/06/jurnal-tamadun.pdf. Lihat juga, Mohd. Zamrus Mohd. Ali, Tradisi Intelektual Andalusia, Pengaruh Disiplin Al-Quran (Pulau Pinang : Penerbit USM, 2016), 23.

27 Ibn Khallikans, Biographical Dictionary, 133. Lihat juga, Gerhard Bowering, The Princeton Encyclopedia of Islamic Political Thought, 233; Thomas Glick, Stevan J. Livesey \& Faith Wallis, Medival Science, Technology And Medicene An Encyclopedia, 243; Hafizah Dasuki, Ensiklopedia Islam, jld. II, 151.

28 Aref Abu Rabia, "Urinary Diseases And Ethnobotany Among Pastoral Nomads in the Middle East", website Journal of Ethnobiology and Ethnomedicine, see http://www.ethnobiomed.com/content/1/1/4\#B10 September 2011. Lihat juga, Thomas Glick, Stevan J. Livesey \& Faith Wallis, Medival Science, Technology and Medicene an Encyclopedia, 246.

29 Ghazali Darusalam, Sumbangan Sarjana dalam Tamadun Islam (Kuala Lumpur: Utusan Publications and Distributors Sdn. Bhd., 2001), 98.

30 Thomas Glick, Stevan J. Livesey \& Faith Wallis, Medival Science, Technology and Medicene an Encyclopedia, 245.

31 Azizan Baharudin, Pengenalan Tamadun Islam di Andalus (Kuala Lumpur: Dewan Bahasa dan Pustaka, 1986), 61. 
Rusyd $^{32}$. Selain itu, al-A'qqad 'Abbas Mahmud turut menyatakan bahawa walaupun Ibn Bajjah dilihat pernah menjadi guru kepada Ibnu Rusyd dalam ilmu falsafah serta terlibat dalam penghasilan karya dan ulasan ke atas falsafah-falsafah Aristotle, namun usaha yang dilakukan oleh Ibn Bajjah tidak dapat menandingi kemasyhuran dan ketokohan yang dimiliki oleh Ibnu Rusyd sama ada semasa hayatnya mahupun hingga kini ${ }^{33}$. Selain itu, Ibn Bajjah juga merupakan guru kepada Ibnu Tufail yang juga salah seorang sarjana di dalam bidang falsafah di Andalusia ${ }^{34}$.

Renan mengatakan dalam bidang falsafah, ada yang mengatakan Ibn Rusyd mempelajari ilmu falsafah dengan Ibn Bajjah. Sedangkan pada waktu itu Ibn Rusyd baru berusia kirakira dua belas tahun ${ }^{35}$. Menurut Muhammad Yūsuf Mūsā, pendapat ini juga turut disokong oleh seorang tokoh orientalis dan pengkaji falsafah Ibn Rusyd, S.Munk yang mengatakan Ibn Bajjah merupakan guru kepada Ibn Rusyd dalam ilmu falsafah ${ }^{36}$.

Pada tahun 1110, pada masa Saragosa jatuh ke tangan Almoravid, Ibn Bajjah ketika itu berusia 20 tahun dan telah menjawat jawatan sebagai wazir kepada Gabenor Barbar, Abu Bakar Ibrahim al-Sharawi, yang lebih dikenali dengan nama Ibn Tafalwit. Beberapa sumber lain juga ada menyebutkan bahawa beliau menjadi wazir kepada Kesultanan Furcia ${ }^{37}$. Ketika Saragosa jatuh ke tangan Raja Alfonso I, Raja Argon pada tahun 512H/ $1118 \mathrm{M}$, Ibn Bajjah pergi ke Seville dan menetap di sana sebagai doktor. Sesudah Seville juga diduduki oleh Raja Alfonso I, beliau berpindah ke Granada. Di Syatibah (selatan Valencia, Sepanyol), beliau dipenjarakan oleh amir setempat atas tuduhan bidaah, tetapi

${ }^{32}$ Uni Iskandar Halib, "Pemikiran Ibn Rushd: Suatu Analisis Berhubung Masalah Falsafah dan Agama dalam Kitab Fașl Al-Maqal" (Disertasi, Universiti Kebangsaan Malaysia, 2005), 19.

33 Al-'Aqqad, Abbas Mahmud, Ibn Rushd (Mesir: Dār al-Ma'ārif, 1971), 22.

${ }^{34}$ Takiruddin Hassan, Pemerintahan Kerajaan Dinasti Bani Umayyah Andalus (Sepanyol), 193.

35 E. Renan, Ibn Rushd wa al-Rushdiyyah, terj. Adil Zu'aitir (Kaherah: Dār Ihyā' Al-Kutub al-'Arabiyyah, 1975), 34.

36 Muḥammad Yūsuf Mūsā, Bayna al-Dīn wa al-Falsafah (Mesir: Dār alMa‘ārif, 1968), 28.

37 Bahagian Analisa dan Penyelidikan, Yayasan Dakwah Islamiah Malaysia dalam Utusan Malaysia (Ruangan Agama), 3 April 2012, 12. 
segera dibebaskan ${ }^{38}$.Ilmu falsafah telah melalui beberapa peringkat perkembangan dan kelemahan. Berlakunya perkembangan yang pesat adalah pada zaman pemerintahan al-Mustansir. Pada ketika itu, orang ramai sentiasa berdamping dengan ulama falsafah seperti mereka berdamping dengan ulama fiqh.

Pada waktu ini juga, banyak buku falsafah terdapat di kutubkhanah di Sepanyol. Apabila tiba zaman pemerintahan Hisyam, suatu tindakan yang bertentangan telah dilakukan ke atas perkembangan ilmu falsafah. Buku-buku berkaitan dengan falsafah dibakar dan para ulamanya diseksa. Tindakan ini adalah kerana desakan ulama fiqh yang tidak bersetuju dengan ilmu falsafah yang dituduhnya zindik dan mulhid ${ }^{39}$. Setelah bebas, beliau pergi ke Fez (kini dikenali Moroko), memasuki istana Gabenor Abu Bakar Yahya Bin Yusuf Bin Tasyfin (Ibn Tasyfin) dan menjadi pegawai tinggi berkat kemampuan dan pengetahuan di istana Murabithin. Beliau memegang jawatan itu selama 20 tahun. Musuh-musuh Ibn Bajjah melebelnya sebagai ahli bid'ah dan beberapa kali terlibat dalam usaha cubaan membunuh terhadapnya. Semua itu gagal akan tetapi akhirnya berjaya dilakukan oleh seorang doktor termasyhur, 'Abd al- A'lā bin Zuhr dengan menggunakan racun. Perkara ini juga digambarkan oleh Jamaluddin al-Qafthi bahawa Ibn Bajjah penah dikhianati oleh sahabat kedoktorannya yang iri hati dengan apa yang dimiliki olehnya. Akhirnya beliau diracuni oleh orang kenalannya sendiri ${ }^{40}$.

Ibn Bajjah meninggal dunia di Fez sana pada bulan Ramadan $533 \mathrm{H} / \mathrm{Mei} 1139 \mathrm{M}^{41}$. Selain itu, antara sebab lain Ibn Bajjah dibunuh adalah, sikap dan prinsip hidup beliau yang memandang sepi terhadap kebendaan serta mengutamakan kerohanian. Ibn Bajjah tidak gemar kepada kebendaan serta kemewahan dunia

38 Gazi Saloon, Jiwa dalam Pandangan Para Filosof Muslim (Bandung: Pustaka Hidayah, 2002), 257.

39 Dusuki Haji Ahmad, Ikhtisar Perkembangan Islam (Kuala Lumpur: Dewan Bahasa dan Pustaka, 1986), 349.

40 A. Mustofa, Filsafat Islam (cet. III, Bandung: CV. Pustaka Setia, 2007), 225. Lihat juga, Hafizah Dasuki , Ensiklopedia Islam, 152.

41 Bahagian Analisa dan Penyelidikan, Yayasan Dakwah Islamiah Malaysia (YADIM) dalam Utusan Malaysia (Ruangan Agama), 3 April 2012,. 12. Lihat juga Ibn Khallikans, Biographical Dictionary, 134. Lihat juga A. Mustofa, Filsafat Islam, 225, Lihat juga, Hafizah Dasuki, Ensiklopedia Islam, 152. 
yang melampau ${ }^{42}$. Oleh sebab itu, di dalam buku beliau yang diterjemahkan ke bahasa Inggeris bertajuk The Rule of the Solitary $^{43}$, Ibn Bajjah mengecam keras golongan materialistik di kalangan golongan bangsawan ketika itu. Hal ini juga antara punca Ibn Bajjah dibunuh oleh golongan bangsawan yang tidak menyenangi sikap beliau yang membenci kehidupan mewah yang melampau dan membawa kepada kealpaan kepada agama seperti golongan yang dikutuk oleh Allah SWT di dalam al-Quran.

\section{Karya-karya Ibn Bajjah}

Ibn Bajjah banyak menghasilkan karya dalam pelbagai bidang. Karya-karya yang dihasilkannya lebih kurang 31 karya. Karya asal Ibn Bajjah ditulis dalam Bahasa Arab dan diterjemahkan ke dalam bahasa Ibrani dan bahasa Latin. Manuskrip asal dan terjemahannya ada tersimpan di dalam Perpustakaan Oxford, Perpustakaan Bodleian, Perpustakaan Berlin ${ }^{44}$ dan Perpustakaan Escurial, Sepanyol ${ }^{45}$. Terdapat hanya dua manuskrip Ibn Bajjah, dipelihara dan dijaga rapi di dalam perpustakaan Oxford dan Berlin.

Antara karya-karya Ibn Bajjah yang terkenal adalah seperti al-Tadbīr al-Mutawahhid, Risālah Ittișal al-'Aqal bi al-Insān, alRisālah al-Wada' (Ilmu Pengubatan), al-Risālah al-Akhlaq, alTarddiyyah (Syair Pujian), Kitab al-Nabāt, Kitab al-Nafs, dan Risālah al-Ghayah al-Insāniyyah. Umpamanya, karyanya Risālah al-Wida' menceritakan tentang ketuhanan, kewujudan manusia, alam serta huraian mengenai kedoktoran serta perubatan. Begitu juga dengan Risalah al-Ittișal al-'Aql bi al-Insān yang mengandungi perhubungan akal dengan manusia serta huraian mengenainya.

Takiruddin Hassan, Pemerintahan Kerajaan Dinasti Bani Umayyah Andalus (Sepanyol), 192.

43 Buku tersebut adalah hasil terjemahan daripada buku Ibn Bajjah yeng bertajuk al-Tadbir al-Mutawahhid. Lihat D.M. Dunlop, "Ibn Bajjah's Tadbirul Mutawahhid (Rule of the Solitary)", The Journal of the Royal Asiatic Society of Great Britain and Ireland, No. 1pp, (April, 1945), 61-81.

44 M.S. Hassan Ma'sumi, Ibn Bajjah's 'Ilm Al-Nafs, 1.

45 Ibn Khallikans, Biographical Dictionary, 133. Lihat juga, Hafizah Dasuki, Ensiklopedia Islam, 152. Lihat juga Maruwiah Ahmat, Ibn Bajjah (Shah Alam: Aspirasi Ayah Bonda Enterprise, 2011), 14. 
Manakala karya Ibn Bajjah yang berjudul al-Nafs pula tentang persoalan yang yang berkaitan dengan jiwa manusia dengan Tuhan dan pencapaian manusia yang tertinggi dari kewujudan manusia (kebahagiaan). Persoalan ini banyak dipengaruhi oleh gagasan pemikiran falsafah Yunani. Oleh sebab itulah Ibn Bajjah banyak membuat ulasan terhadap karya dan hasil tulisan Aristotle, Galen, al-Farabi dan al-Razi. Kitab al-Nafs ini adalah hasil huraian dan penjelasan daripada tulisan Aristotle iaitu De Anima. Ibn Bajjah telah mengkaji dengan terperinci tulisan tersebut dan hasilnya, falsafah Aristotle ini diketengahkan menurut pandangan yang lebih Islamik dan tauhidik. Kitab al-Nafs sentiasa dirujuk oleh Ibn Bajjah dalam terma-terma yang jelas menunjukkan bahawa ia adalah karyanya yang asal dan bebas, serta komentar kepada karya-karya Aristotle. Terdapat sebelas bab di dalam buku ini yang menghuraikan secara terperinci tentang manusia $^{46}$. Kesemua bab tersebut membincangkan tentang manusia dan kehidupan. Manusia tidak dapat hidup melainkan ada sesuatu yang menggerakkannya. Maka apabila jiwa dan manusia berhubung dan saling lengkap melengkapi yang akhirnya membuatkan manusia itu hidup dan menjalani kehidupan manusiawi.

Antara lain karya terbesar Ibn Bajjah ialah al-Tadbìr alMutawahid dan al-Risālah Ittișal al- 'Aqal bi al-Insān yang mana ianya menekankan mengenai tema klasik tentang aspek gerakan intelektualisme dari keadaan potensi ke dalam keadaan nyata dan kontrak terakhir akal 'perolehan' dengan akal yang 'aktif' yang hanya menjadi hak istimewa dari sebahagian kecil manusia yang mampu mencapainya. Melalui Ibn Bajjah, falsafah Aristotle telah bertukar wajah menjadi wajah Islami ${ }^{47}$.

Menurut Harun Nasution, Ibn Bajjah telah mempelajari dan memahami falsafah Aristotle dengan baik dan kerana itu, persoalan yang dimajukan oleh beliau seringkali condong kepada pandangan Aristotle. Namun, Ibn Bajjah berupaya mengolah persoalan metafizik Aristotle tersebut menurut pandangan Islam. Oleh kerana itu, menurut Ibn Bajjah Allah SWT tidak hanya bergerak tetapi Allah adalah pencipta dan Pengatur seluruh alam.

\footnotetext{
46 M.S. Hassan Ma'sumi, Ibn Bajjah's 'Ilm Al-Nafs, 3.

47 Kāmil Muḥammad Muḥammad U'waiḍah, Ibn Bajjah al-Andālūsī al-Faylāsuf al-Khallaq, 117-118.
} 
Akan tetapi, huraian Ibn Bajjah secara umum dalam bidang ini belum sempurna. Penerangan yang lebih sempurna dalam hal ini dapat dilihat dalam falsafah Ibnu Tufail dan Ibnu Rusyd ${ }^{48}$. Keduadua ilmuwan tersebut merupakan anak murid kepada Ibn Bajjah ${ }^{49}$. Kitab Ibn Bajjah, al-Tadbīr al-Mutawahid (Pentadbiran Seorang Yang Menyendiri) merupakan sebuah buku falsafah. Buku tersebut menerangkan tentang pegangan falsafah beliau sendiri. Menurut Ibn Bajjah di dalam bukunya itu, hanya melalui pegangan serta keyakinan kepada kewujudan dan kekuasaan Allah SWT sahaja akan membuatkan seseorang manusia itu mendapat kebahagiaan dan ketenangan di dalam hidupnya ${ }^{50}$. Buku ini juga turut membahas tema pengasingan diri ${ }^{51}$. Karya Ibn Bajjah ini telah dinilai oleh Ibnu Tufail sebagai karya yang tidak lengkap. Justeru, Ibnu Tufail mengambil inisiatif dengan menulis sebuah karya kisah Hayy Ibn Yaqzan ${ }^{52}$.

Falsafah pemikiran telah bertukar menjadi etika hidup yang memprotes pandangan materialistik dan duniawi serta ianya menjadi amalan pada ketika itu. Hal ini jelas di dalam karya Ibn Bajjah berkenaan Adāb al- 'Uzlah (Cara Mengasingkan Diri). Pada pendapat beliau, jika kita melihat kebodohan umum, maka kita wajib menjauhkan diri paling tidak dalam pemikiran ${ }^{53}$. Ibn Bajjah telah menulis beberapa huraian atau kupasan tentang karangan Aristotle berkaitan ilmu lojik (ilmu mantiq), metafizik dan lainlain. Beliau juga sering merujuk kepada Plato, Aristotle, Galen, alFarabi, Ibnu Sina dan al-Ghazali di dalam buku-buku karangannya. Karya beliau sangat banyak di dalam bidang ilmu falsafah dan kesemuanya ditulis di dalam bahasa Arab dan kemudiannya diterjemahkan ke dalam bahasa Hebrew atau Ibrani (Yahudi) seterusnya ke bahasa Latin dan akhirnya ke bahasa

48 Harun, Falsafah Agama (Jakarta: Percetakan Bulan Bintang, 1973), 17.

49 Takiruddin Hassan, Pemerintahan Kerajaan Dinasti Bani Umayyah Andalus (Sepanyol), 193. Lihat juga 'Abbās Maḥmūd al-'Aqqad, Ibn Rushd, 22. Lihat juga E. Renan, Ibn Rushd wa al-Rushdiyyah, 34.

50 Takiruddin Hassan, Pemerintahan Kerajaan Dinasti Bani Umayyah Andalus (Sepanyol), 192.

51 Cyril Glasse, Ensiklopedia Islam (ringkas) (Jakarta: PT Raja Grafindo Persada, 1999), 148.

52 M. Hadi Masruri, Ibn Tufail: Jalan Pencerahan Mencari Tuhan (Yogyakarta : PT Lkis Pelangi Aksara, 2005), 39.

53 Dusuki Haji Ahmad, Ikhtisar Perkembangan Islam (Kuala Lumpur: Dewan Bahasa dan Pustaka, 1986), 351. 
Inggeris. Buku karangan beliau yang bertajuk Majmu' kini disimpan di perpustakaan Berlin, Jerman dan salinannya di Oxford, England ${ }^{54}$.

Menurut Hafizah, daripada tiga puluh satu karya Ibn Bajjah yang telah diperkenalkan, tidak ada satu pun karya beliau yang halamannya melebihi tiga puluh halaman folio. Antara karyakaryanya termasuklah Tadbīr al-Mutawwāhid, Risālah Ittișal al'Alq bi al-Insān, Risālah al-Wada (ilmu pengubatan), Risalah alAkhlāq, Tardiyyah (Syair Pujian), Kitab Nabāt, Kitab al-Nafs dan Risālah al-Gayah al-Insaniah ${ }^{55}$. Sumbangan Ibn Bajjah turut direkodkan dalam banyak penulisan ilmiah $^{56}$. Karya-karya Ibn Bajjah karya-karyanya yang disenaraikan seperti Tadbìr alMutawāhnid, Risālah Ittișal al- 'Alq bi al-Insān, Risālah al-Wada (ilmu pengubatan), Risālah al- Akhlāq, Tardiyyah (Syair Pujian),

54 Takiruddin Hassan, Pemerintahan Kerajaan Dinasti Bani Umayyah Andalus (Sepanyol), 191.

55 Hafizah Dasuki, Ensiklopedia Islam, 152.

56 Menurut Ibn Tufail, generasi pertama sarjana Andalus menceburkan diri dengan pengajian matematik dan generasi berikutnya memberi sumbangan yang jelas terhadap pengajian ilmu logik. Akan tetapi sumbangan mereka itu kurang lengkap berbanding dengan generasi pertama. Akhirnya sebuah kelompok baru para sarjana yang lebih arif dalam bidang ilmu falsafah abstrak, telah muncul pada waktu itu. Ibn Bajjah berada dalam kelompok terakhir ini. Oleh kerana itulah beliau dapat dikategorikan sebagai tokoh utama yang pertama dalam sejarah falsafah Arab Andalus. Ibn Bajjah juga merupakan seorang yang menguasai ilmu fizik ${ }^{56}$. Dalam bidang fizik, 'Teori Avempace' yang dikemukakan oleh Ibn Bajjah telah mempengaruhi pemikiran Galilieo sehingga beliau berjaya menghasilkan idea-idea baru tentang hukum-hukum pergerakkan moden. Galilieo telah menggunakan formula Ibn Bajjah dalam buku beliau yang bertajuk Pisan Dialogne. Teori yang digunakan oleh Galilieo ini bertentangan dengan teori yang pernah diperkenalkan oleh Aristotle. Teori Avempace ini turut disokong oleh St. Thomas dan Duns Scotus ${ }^{56}$. Selain daripada seorang ahli muzik dan pemain gambus yang handal, Ibn Bajjah juga merupakan seorang yang terkenal dalam bidang perubatan dan merupakan doktor Andalusia yang tersohor. Kehebatannya juga terserlah dalam bidang politik. Ibn Bajjah pernah dilantik menjadi menteri di Saragosa. Selain itu, beliau turut menguasai ilmu matematik, fizik dan astronomi dengan baik. Oleh itu, Ibn Bajjah turut berperanan dalam mengembangkan ilmu astronomi Islam. Seorang ilmuwan Yahudi dari Andalusia, Moses Maimonides menyatakan bahawa Ibn Bajjah telah mencetuskan sebuah model planet. Ibn Bajjah juga turut mengungkapkan teori Galaksi Bima Sakti. Beliau menegaskan bahawa Galaksi Bima Sakti sebagai sebuah fenomena luar angkasa yang terjadi di atas bulan dan wilayah sub-bulan. 
Kitab al-Nafs dan Risālah al-Gayah al-Insāniyah menekankan tentang proses pembangunan jiwa berasaskan kepada konsep AlNafs.

\section{Pembangunan Jiwa Berasaskan Konsep al-Nafs Menurut Ibn Bajjah}

Ibn Bajjah telah menyatakan konsep al-Nafs secara holistik. Beliau turut menyatakan bahawa kesempurnaan kejadian manusia akan membawa kepada mengenal diri sendiri seterusnya mengenali Pencipta (Allah SWT) dan sekaligus mengimaninya. Ibn Bajjah juga turut membuktikan bahawa akal yang terdapat pada manusia dan hubungan hamba dengan Allah SWT selaku Pencipta sekelian alam tidak dapat dipisahkan. Ianya berhubung melalui pemikiran yang sempurna. Ibn Bajjah juga turut mengintergrasikan akal, pemikiran dan keesaan Allah SWT saling berhubung di antara satu sama lain dalam konteks al-Nafs. Maka, di sinilah lahirnya pembangunan jiwa berasaskan konsep al-Nafs menurut Ibn Bajjah.

Manusia dianugerahkan akal oleh Allah SWT. Melalui akal, manusia dapat menimbang dan memikirkan mana yang baik dan mana yang buruk. Juga dapat memikirkan mana yang bermanfaat dan mana yang boleh mendatangkan mudharat. Oleh sebab itu, Allah SWT telah menyediakan untuk orang yang beriman dan melakukan kebaikan, maka balasannya adalah syurga serta kesenangan. Manakala untuk orang kafir dan mereka yang melakukan kejahatan pula, tempatnya adalah di neraka yang sangat pedih seksaannya ${ }^{57}$.

Justeru, pembangunan jiwa menurut Ibn Bajjah melalui pandangannya mengenai konsep al-Nafs telah memberi garis panduan bahawa pembangunan jiwa setiap Muslim melalui konsep al-Nafs, ilmu, pemikiran dan tauhid adalah saling berhubung di antara satu sama lain serta merupakan kesatuan yang hakiki. Pembangunan jiwa dan konsep al-Nafs dalam konteks mengesakan Allah SWT tidak dapat dipisahkan kerana ia akan membentuk pemikiran yang bakal melahirkan individu lain daripada yang lain.

57 Mahmud Yunus, Al-Quran Terjemahan dan Tafsir Mukhtasar (Selangor: Darul Furqaan, 2013), 922. 
Oleh yang demikian, manusia sebagai hamba ciptaan-Nya, perlu sedar akan tanggungjawab dan amanah yang diperintahkan malah akan dipertanggungjawabkan di akhirat nanti. Justeru, pembangunan jiwa melalui konsep mengesakan Allah SWT seharusnya menjadi sebahagian dalam kehidupan manusiawi bagi menjaga statusnya sebagai khalifah Allah SWT di muka bumi ini. Para ilmuwan dahulu, mereka menguasai pelbagai bidang keilmuan, namun mereka tetap menghubungkan hati mereka dengan Allah SWT. Ibn Bajjah telah mengutarakan bahawa setiap ilmu itu pasti akan bertunjangkan tauhid. Hal ini kerana semua ilmu adalah milik Allah SWT yang dikurniakan kepada setiap hamba-Nya menerusi ilham ${ }^{58}$ dan juga pengalaman. Contohnya, ilham, pengalaman dan pengajaran yang Allah SWT berikan kepada manusia menerusi kisah Habil dan Qabil ${ }^{59}$.

Sehubungan dengan itu, berdasarkan konsep al-Nafs menurut Ibn Bajjah menyatakan bahawa landasan utama dalam pembangunan jiwa melalui pemikiran Islam adalah keyakinan bahawa Allah SWT sebagai Pencipta, Pentadbir dan Penguasa ke atas alam ini seluruhnya. Allah SWT hanya satu-satunya Tuhan yang menjadikan manusia dan kehidupan. Keyakinan yang tinggi bahawa Allah SWT sebagai Pencipta telah mencorakkan disiplin atau syariat yang sempurna untuk diikuti. Mengikut syariat Allah SWT bukan bermaksud paksaan, sebaliknya atas kesedaran yang jitu bahawa Allah SWT itu benar-benar Maha Kaya, Maha Adil

58 Ilham bermaksud menelan, meneguk, mengajar, mewahyukan sesuatu yang disampaikan Allah s.w.t ke dalam jiwa yang membangkitkannya untuk mengerja atau meninggalkan sesuatu. Lihat Hafizah Dasuki, Ensiklopedia Islam, 2:199.

59 Ilham yang Allah s.w.t berikan kepada Qabil untuk menguburkan mayat saudaranya Habil seperti firman Allah s.w.t di dalam surah al-Maidah ayat 31 yang mafhumnya: "Kemudian Allah mengutus seekor burung gagak menggali tanah (untuk menguburkan burung gagak yang lain yang mati) untuk memperlihatkan kepadanya (Qabil) bagaimana dia seharusnya menguburkan mayat saudaranya. Qabil berkata, 'Oh, celaka aku! Mengapa aku tidak mampu berbuat seperti burung gagak ini, sehingga aku dapat menguburkan mayat saudaraku ini?' Maka jadilah dia termasuk orang yang menyesal". (Dari ayat ini dapat difahami, bahawa manusia banyak pula mengambil pengajaran dari alam dan agar mereka tidak segan-segan mengambil pengajaran dari yang lebih rendah tingkatan pengetahuannya.) Lihat Ahmad bin Musthafa al-Farran, Tafsir Imam Syafi'i (Jakarta Timur: Penerbit Almahira, 2008), 2:332. 
dan Maha Sempurna. Kegagalan manusia mentaati perintah Allah SWT dalam bidang syariat, menandakan kegagalan manusia mengenali Penciptanya sendiri.

Kesimpulannya, pembangunan jiwa berasaskan konsep alNafs menurut Ibn Bajjah akan melahirkan insan yang sentiasa menghubungkan dirinya dengan Allah SWT. malah, meletakkan bahawa segala sesuatu itu adalah milik Allah. Justeru, manusia harus sedar bahawa segala yang ada di dunia ini tidak akan kekal. Sebaliknya, daripada Allah kita datang dan kepada Allah jua kita akan dikembalikan. Segala-galanya adalah milik Allah SWT jua.

Rajah di halaman sebelah menerangkan pandangan umum alNafs menurut Ibn Bajjah. Menurut Ibn Bajjah al-Nafs itu adalah diri manusia. Oleh kerana itu, Ibn Bajjah telah mendefinisikan alNafs kepada dua takrifan. Iaitu tabiat dan roh. Kedua-dua ini terdapat pada manusia. Tabiat umpamanya dilihat oleh Ibn Bajjah sebagai sifat yang menumpang kepada manusia. Tabiat tidak boleh berdiri dengan sendiri, sebaliknya ia perlu berada pada manusia yang hidup. Hal ini kerana, dengan tabiat manusia itu bergerak dan melakukan sesuatu. Manakala roh pula, Ibn Bajjah melihat ianya juga perlu menumpang pada jasad manusia. Roh sahaja tidak mampu untuk melakukan apa-apa. Sebaliknya roh perlu kepada jasad untuk melakukan sesuatu. Jasad manusia pula tidak dapat bergerak tanpa roh. Hal ini bermakna kedua-duanya saling perlu memerlukan antara satu sama lain. Gabungan roh, jasad dan tabiat telah melengkapkan diri manusia yang ditafsirkan oleh Ibn Bajjah sebagai al-Nafs yang sempurna.

Menurut Ibn Bajjah kesempurnaan manusia itu terdapat di dalam dua keadaan iaitu kesempurnaan dalaman dan luaran. Kesempurnaan dalaman itu adalah kepandaian manusia yang tidak ditunjukkan ataupun diajari. Manakala kesempurnaan luaran pula adalah kepandaian dan kebijaksanaan yang diterjemahkan untuk manfaat umum. Justeru, takrifan al-Nafs Ibn Bajjah menjadi lebih kompleks. Hal ini kerana Ibn Bajjah meneliti setiap inci bagi istilah al-Nafs yang natijahnya membentuk manusia. 
Al-Nafs dengan Kepelbagaian Dimensi Menurut Ibn Bajjah

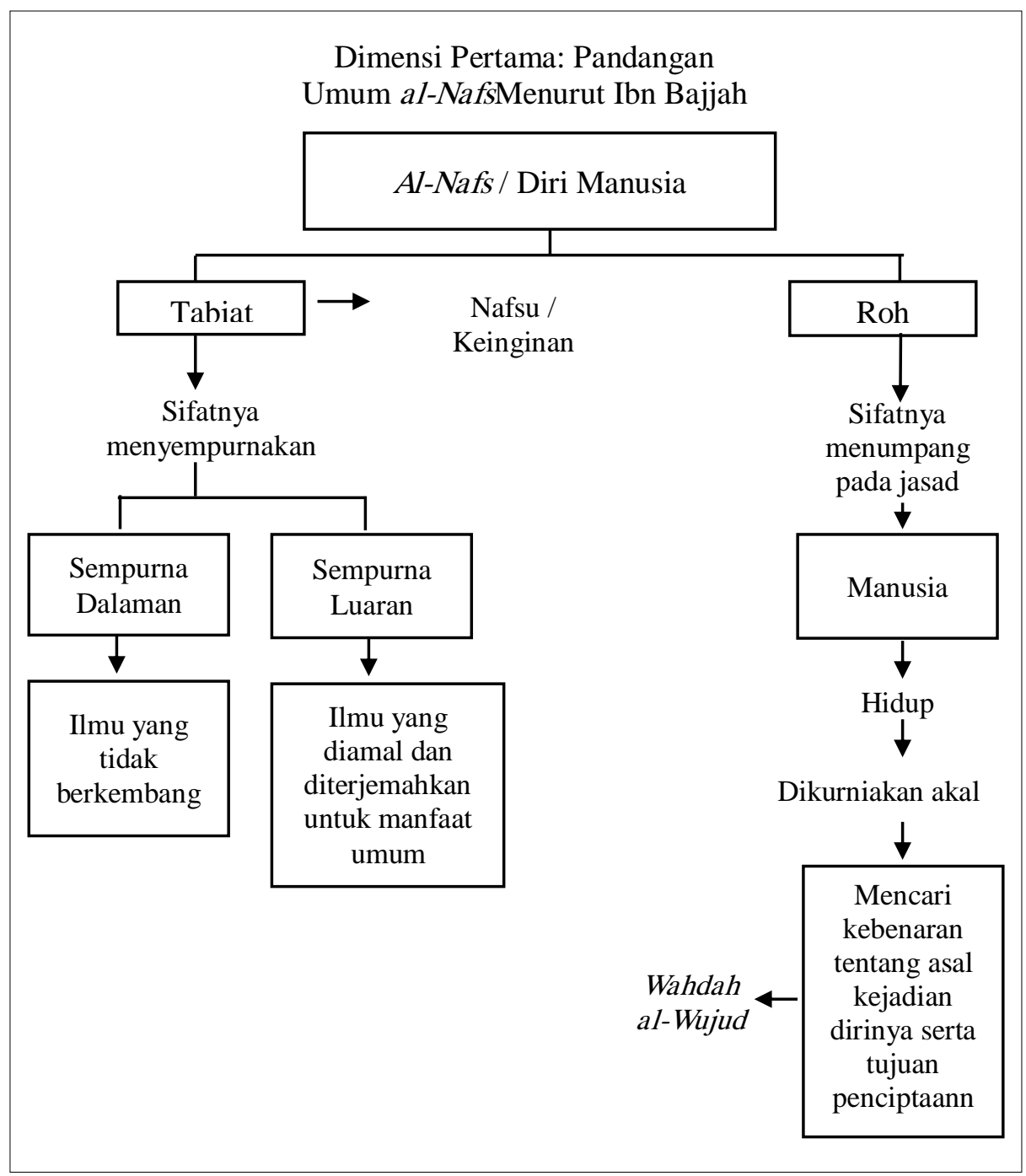

Rajah 1: Pandangan umum al-Nafs menurut Ibn 
Rajah di halaman sebelah pula adalah pandangan menyeluruh pembangunan jiwa menurut Ibn Bajjah. Pembangunan jiwa juga turut dikaitkan dengan pembangunan al-Nafs secara keseluruhannya. Dalam menjelaskan pembangunan al-Nafs secara menyeluruh, Ibn Bajjah menegaskan bahawa manusia yang dikurniakan akal harus diterjemahkan kepada sesuatu yang difikirkan berkaitan perilaku dan perbuatan. Dalam konteks ini, Ibn Bajjah menyatakan diri manusia sentiasa bersedia menerima ilmu pengetahuan. Proses penerimaan ilmu membuktikan manusia mempunyai akal fikiran. Justeru, akal fikiran itu dimanfaatkan untuk berfikir, mempelajari sesuatu, mengingati dan sebagainya. Tegasnya, proses menerima ilmu pengetahuan dan berfikir untuk mendapatkan jawapan akan menjadikan manusia itu sempurna.

Ibn Bajjah juga mengatakan bahawa sesiapa yang tidak mengetahui asal sesuatu perkara melalui pemikirannya, maka semua ilmunya itu salah. Di sinilah tauhid mula bertaut di dalam pemikiran Ibn Bajjah. Hal ini kerana setiap sesuatu pasti ada asalnya. Justeru, manusia harus berfikir tentang asal kejadiannya. Manusia yang berfikir, pasti akan mendapat jawapannya. Hal ini kerana asal manusia adalah dijadikan oleh Allah SWT. seperti yang telah termaktub di dalam al-Quran menerusi surah al-Insan ayat 1 hingga 3 . Ilmu itu adalah cahaya yang pasti akan menerangi akal sehingga ianya akan menjumpai asal sesuatu perkara. Menurut Ibn Bajjah lagi, setiap akal yang ada pada manusia itu tersembunyi. Maka apabila manusia mengetahui dan mempelajari sesuatu, pada ketika itu akal akan menjadi lebih sempurna. Apabila akal manusia diterjemahkan kepada perbuatan, ianya akan membuktikan segalanya ada Pencipta (Allah SWT). Hal inilah yang dinamakan oleh Ibn Bajjah sebagai "Wehdatul Wujud" iaitu adanya Tuhan maka adanya makhluk dan kewujudan Tuhan itu dengan zat-Nya sendiri serta tidak berhajat kepada makhluk. Maka berfikir tentang kewujudan diri itu akan menemukan dengan wujudnya Tuhan (Allah SWT ).

Ibn Bajjah telah membahagikan manusia itu kepada dua kelompok. Pertama, kelompok yang dikenali sebagai 'Manusia Haiwan' atau 'Insan Bahimi' iaitu manusia dari kelompok ini adalah mereka yang suka memperturuti hawa nafsu dan mereka dipandu serta dikuasai oleh hawa nafsu. Manakala kelompok yang kedua pula adalah manusia yang berfikir secara teori dan 


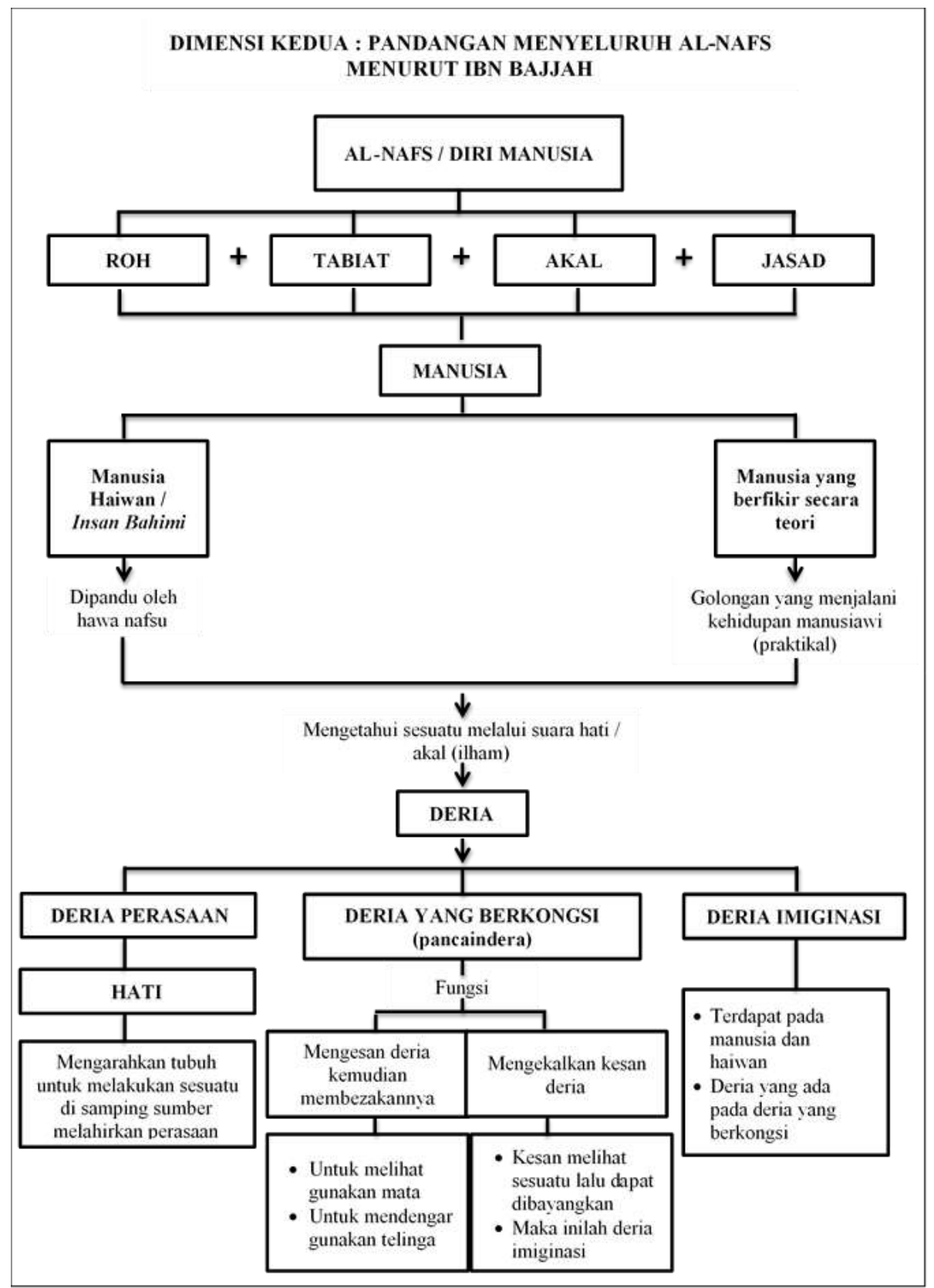

Rajah 5.2 : Pandangan menyeluruh al-Nafs menurut Ibn Bajjah 
menggunakan akal fikiran serta bertindak berpandukan akal yang sempurna. Seterusnya, kelompok ini adalah golongan manusia yang menjalani kehidupan dan memenuhi tuntutan kehidupan manusiawi. Kedua-dua kelompok manusia ini yang akan menghasilkan idea-idea yang sempurna yang diperolehi daripada suara hati atau akal atau istilah yang lebih tepat adalah ilham.

Ibn Bajjah juga membicarakan tentang deria yang terdapat pada manusia. Ibn Bajjah membahagikan deria manusia itu kepada tiga bahagian, iaitu deria perasaan, deria yang berkongsi dan deria imiginasi. Menurut Ibn Bajjah, deria perasaan itu adalah hati manusia yang melahirkan perasaan dan keinginan. Deria yang berkongsi pula, adalah deria yang menggunakan seluruh pancaindera manusia. Manakala bagi deria yang ketiga pula adalah deria imiginasi. Dalam hal ini, deria imiginasi inilah yang telah melengkapkan haiwan kerana haiwan tidak dikurniakan akal. Oleh yang demikian, haiwan menggunakan deria imiginasi ini untuk hidup dan juga berusaha untuk kelangsungan hidup seperti berburu, mengawan dan sebagainya. Oleh itu, deria imiginasi ini yang menjadikan haiwan-haiwan tersebut lebih sempurna. AlGhazali menyatakan bahawa manusia juga termasuk di dalam kelompok haiwan. Tetapi, manusia dibezakan dengan adanya hati, akal dan budi ini yang menjadikan manusia itu istimewa.

Dalam pada itu, Ibn Bajjah membezakan antara manusia dan haiwan. Hal ini kerana kelebihan manusia itu adalah pada akalnya yang dapat menentukan sesuatu itu benar atau salah. Menurut Ibn Bajjah, mengetahui akan sesuatu perkara, mempunyai dua kelazatan. Pertama, kelazatan dalam keyakinan ketika manusia mengetahui sesuatu perkara itu benar atau salah. Manakala kelazatan yang kedua pula ialah kelazatan mengetahui sesuatu perkara yang baharu.

Kesimpulannya, Ibn Bajjah dalam merungkaikan pembangunan jiwa menyatakan bahawa manusia yang paling rendah kedudukannya sama sekali tidak boleh disamakan dengan haiwan kerana manusia itu masih lagi berkemampuan hidup bermasyarakat. Selain itu, Ibn Bajjah juga turut berpendapat, tujuan utama kekuatan akal adalah supaya dapat terhasilnya hikmah. Oleh sebab itu, menurut Ibn Bajjah penggerak utama manusia adalah akal dan akal dapat digunakan untuk sampai ke sesuatu tujuan dan kehendak serta berkongsi dengan orang lain 
apa yang diperolehinya. Maka hasil gabungan al-Nafs dan akal telah menggerakkan deria perasaan, deria yang berkongsi beserta deria imiginasi yang tinggi yang telah menghasilkan falsafah hidup manusia serta mempunyai sebuah tamadun.

\section{Penutup}

Ibn Bajjah telah membincangkan secara jelas tentang pembangunan jiwa berasaskan konsep al-Nafs dalam menghuraikan tentang diri manusia. Ibn Bajjah telah melihat alNafs di dalam pelbagai dimensi kerana konsep al-Nafs yang diutarakan oleh Ibn Bajjah menyentuh secara menyeluruh tentang manusia yang sebenarnya. Pelbagai gabungan unsur-unsur yang telah menyempurnakan manusia itu melayakkannya diberi gelaran khalifah di atas muka bumi ini. Justeru, Ibn Bajjah telah menghubungkan akal dengan keesaan Allah SWT. Dalam hal ini, akal yang jernih dan sempurna pasti akan mencari jawapan bagi setiap persoalan yang timbul dengan Pencipta yang Maha Agong (Allah SWT). Tegas Ibn Bajjah bahawa, ketinggian akal itu pasti akan terarah mencari kebenaran dan hakikat penciptaan manusia itu tidak lain hanyalah untuk mengesakan Allah SWT selain daripada melaksanakan tuntutan seorang hamba kepada Tuhannya (Allah SWT).

Ibn Bajjah juga menjelaskan tentang hakikat penciptaan manusia. Selain itu, manusia dilihat sebagai makhluk yang hebat berbanding dengan makhluk-makhluk yang lain. Hal ini kerana kelebihan manusia itu terletak pada akalnya. Justeru, Ibn Bajjah telah menjelaskan secara lengkap tentang manusia dan menekankan bahawa manusia tidak akan dapat bergerak sekiranya tiada yang akan menggerakkannya. Oleh kerana itu, terdapat beberapa unsur di dalam diri manusia yang selayaknya bergelar manusia, iaitu al-Nafs. Justeru, pembangunan jiwa adalah pembangunan al-Nafs yang holistik dilihat penting dalam kehidupan manusiawi untuk difahami secara ilmiah dalam usaha melahirkan hubungan yang harmoni antara hamba yang dicipta dengan Pencipta semesta alam. 


\section{Rujukan}

Sulaiman Noordin. Sains: Falsafah dan Islam. Bangi: Universiti Kebangsaan Malaysia, 1993.

Chejne, Anwar G. Muslim Spain: It's History and Culture. Minneapolis: The University of Minnesota Press, 1974.

Rasid Muhamad. Merintis Kecemerlangan Islam: Sumbangan, Cabaran dan Masa Hadapan Umat Muhammad. Kuala Lumpur: Karya Bestari, 2010.

Che Zaharah Abdullah. "Sumbangan dan Pengaruh Intelek Muslim Kepada Masyarakat: Kajian di Bandar Baru Bangi". Disertasi, Universiti Kebangsaan Malaysia, 2001.

Khallikans, Ibn. terj. Mac Guckin De Slane. Biographical Dictionary, translated from the Arabic. Paris: Paris Printed, t.t.), vol. III: 134.

U'waị̣ah, Kāmil Muḥammad Muḥammad. Ibn Bajjah al-Andālūsī al-Faylāsuf al-Khallaq. Beirut, Lubnan: Dār al-Kutub al'Ilmiyyah, 1993.

Hafizah Dasuki. Ensiklopedia Islam, jld. II. Kuala Lumpur: Dewan Pustaka dan Bahasa, 2004.

Takiruddin Hassan. Pemerintahan Kerajaan Dinasti Bani Umayyah Andalus (Sepanyol). Johor Bahru: Perniagaan Jahabersa, 2013.

Gazi Saloon. Jiwa dalam Pandangan Para Filosof Muslim. Bandung: Pustaka Hidayah, 2002.

Ziyādah, Ma'an. Al-Harakah min al-Ṭabī'ah ilā ma Ba'da alTabī'ah Dirāsah fì Falsafah Ibn Bajjah al-Andalus. Beirut, Lubnan: Dār Iqra', 1985.

Ma'sumi, M.S. Hassan. Ibn Bajjah's 'Ilm Al-Nafs. New Delhi: Kitab Bhavan, 1992.

Uni Iskandar Halib. "Pemikiran Ibn Rushd: Suatu Analisis Berhubung Masalah Falsafah dan Agama dalam Kitab Faṣl AlMaqal". Tesis kedoktoran, Universiti Kebangsaan Malaysia, 2005.

Glick, Thomas, Livesey Stevan J. \& Wallis, Faith. Medival Science, Technology and Medicene an Encyclopedia. New York : Routledge Taylor \& Francis Group, 2005.

Ragep, F. Jamil, Ragep Sally P. \& Livesey, Steven. "Tradition, Transmission Transformation". Proceedings of Two 
Conferences on Pre-Modern Science, University of Oklahoma. New York : E.J. Brill, 1996.

Bowering, Gerhard. The Princeton Encyclopedia of Islamic Political Thought. New Jersey: Princeton University Press, 2013.

Khan, Mohammad Shaif. Muslim Philosophy and Philosophers. New Delhi: Computer Codes, 1994.

Mohd Zamrus Mohd Ali. "Disiplin al-Quran dan Hubungannya dengan Tradisi Intelektual Andalusia". Disertasi, Universiti Sains Malaysia, 2010.

Zulkifli Hasan dan Hanani Harun. "Sumbangan Intelektual Islam dalam Seni," Jurnal Tamadun (2008), lihat http://zulkiflihasan.files.wordpress.com/2008/06/jurnaltamadun.pdf.

Mohd. Zamrus Mohd. Ali. Tradisi Intelektual Andalusia, Pengaruh Disiplin Al-Quran. Pulau Pinang: Penerbit USM, 2016.

Rabia, Aref Abu. "Urinary Diseases And Ethnobotany Among Pastoral Nomads in the Middle East", website Journal of Ethnobiology and Ethnomedicine, see http://www.ethnobiomed.com/content/1/1/4\#B10 - September 2011.

Ghazali Darusalam. Sumbangan Sarjana dalam Tamadun Islam. Kuala Lumpur: Utusan Publications and Distributors Sdn. Bhd., 2001.

Azizan Baharudin. Pengenalan Tamadun Islam di Andalus. Kuala Lumpur: Dewan Bahasa dan Pustaka, 1986.

Uni Iskandar Halib. "Pemikiran Ibn Rushd: Suatu Analisis Berhubung Masalah Falsafah dan Agama dalam Kitab Faṣl AlMaqal". Tesis kedoktoran, Universiti Kebangsaan Malaysia, 2005.

Al-'Aqqad, Abbas Mahmud. Ibn Rushd. Mesir: Dār al-Ma'ārif, 1971.

Renan, E., Ibn Rushd wa al-Rushdiyyah. Terj. Adil Zu'aitir. Kaherah: Dār Ihyā’ Al-Kutub al-'Arabiyyah, 1975.

Mūsā, Muhạmmad Yūsuf. Bayna al-Dīn wa al-Falsafah. Mesir:

Dār al-Ma‘ārif, 1968. 
Bahagian Analisa dan Penyelidikan. Yayasan Dakwah Islamiah Malaysia dalam Utusan Malaysia (Ruangan Agama), 3 April 2012, 12.

Dusuki Haji Ahmad. Ikhtisar Perkembangan Islam. Kuala Lumpur: Dewan Bahasa dan Pustaka, 1986.

A. Mustofa. Filsafat Islam. Cet. III, Bandung: CV. Pustaka Setia, 2007

Dunlop, D.M. "Ibn Bajjah's Tadbirul Mutawahhid (Rule of the Solitary)", The Journal of the Royal Asiatic Society of Great Britain and Ireland, No. 1pp, (April, 1945), 61-81.

Maruwiah Ahmat. Ibn Bajjah. Shah Alam: Aspirasi Ayah Bonda Enterprise, 2011.

Harun. Falsafah Agama. Jakarta: Percetakan Bulan Bintang, 1973. Glasse, Cyril. Ensiklopedia Islam (ringkas). Jakarta: PT Raja Grafindo Persada, 1999.

Masruri, M. Hadi. Ibn Tufail: Jalan Pencerahan Mencari Tuhan. Yogyakarta : PT Lkis Pelangi Aksara, 2005.

Ahmad, Dusuki Haji. Ikhtisar Perkembangan Islam. Kuala Lumpur: Dewan Bahasa dan Pustaka, 1986.

Mahmud Yunus. Al-Quran Terjemahan dan Tafsir Mukhtasar. Selangor: Darul Furqaan, 2013.

Ahmad bin Musthafa al-Farran. Tafsir Imam Syafi'i. Jakarta Timur: Penerbit Almahira, 2008. 